
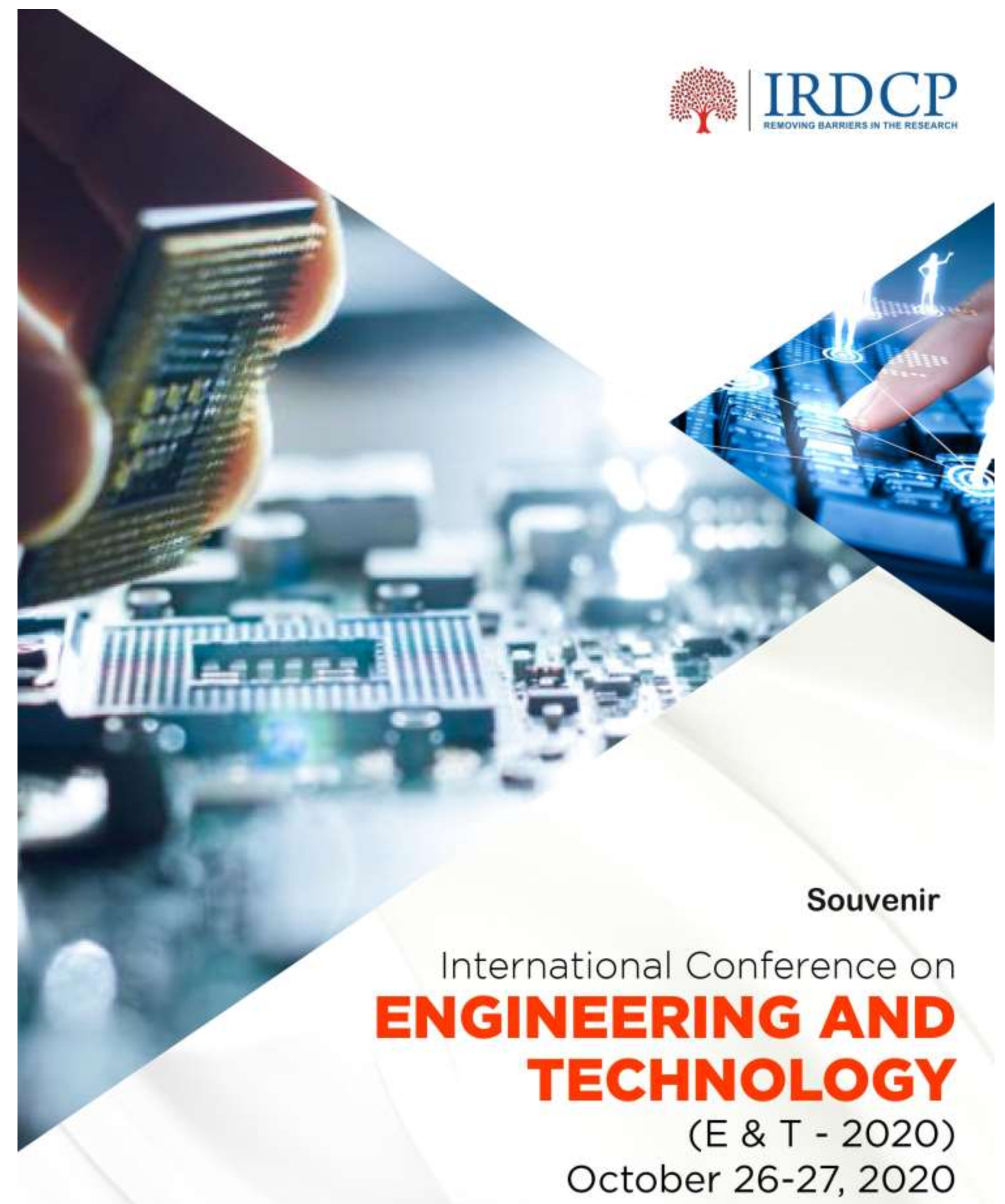

International Research and Development Center for Publication (IRDCP)

www.irdcp.org 


\section{International Conference}

\section{on}

Engineering and Technology

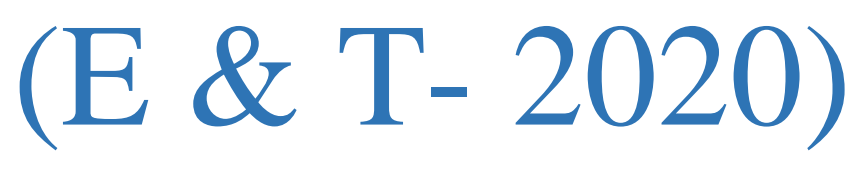

Oct 26-27, 2020

Copyright ( 2020 International Research and Development Center for Publication

DOI: $\underline{10.22161 / \text { conf.et.oct.2020 }}$

\section{Publisher}

\section{IRDCP}

Email: irdcp.publication@gmail.com |conference.irdcp@gmail.com

Web: https://irdcp.org/ 


\section{$\underline{\text { About IRDCP }}$}

International Research and Development Center for Publication (IRDCP) is a nonprofit organization for promoting research and development around the world. IRDCP is the bridge between the quality publisher and researchers. It provides the platform to researchers and academicians for publication in the Scopus Indexed Journals, SCI Journals, Web of Science Journals, UGC Approved Journals, NAAS Rated Journals, Google Scholar Indexed Journals and other good quality DOI journals.

IRDCP is also a partner organization for publication in conference proceedings. We organize the International conferences for publication in SCOPUS indexed and other refereed journals as per the requirement of the authors of the manuscripts. The manuscripts submitted to IRDCP should be plagiarism free and well coherent in all sense.

The scope of publication with the IRDCP covers all type of review and research manuscripts including the Exploratory \& Explanatory Research, Descriptive \& Theoretical Research, Applied Research \& Action Research, Cross-Sectional Research, Quantitative \& Qualitative Research in the field of engineering \& technology, agriculture \& environmental, Social science \& Humanities, Literature \& Education development, Medical \& Health Science.

\section{The vision of IRDCP :}

IRDCP endeavors to promote global excellence in the field of research \& development through diligent applications of advanced technology for the holistic development of society. Also, IRDCP is committed to motivate and persuade the researchers to take up the projects for the continuous development of human society and make this world a better place to live in. The IRDCP has a steadfast commitment be the fulcrum of the ocean of knowledge around which efforts of researchers move about. 


\section{$\underline{\text { About Conference }}$ \\ International Conference on Engineering and Technology \\ $(E \& T-2020)$}

During the worldwide lockdown due to COVID 19 pandemic, a lot of important activities have come to a halt. However, when we look at the brighter side, all of us have more time for adding to our knowledge and insights.

With this aim, to keep contributing to learning and motivation International research and development Center for publication is going to organize a two-day International Conference with the title "International Conference on Engineering and Technology (E \& T- 2020)" on Oct 26-27, 2020 through online mode.

We hope, this online mode of the conference in COVID-19 pandemic will be an appreciable step in promoting the research activities and new information between researchers, developers, students, academicians and practitioners working in and around the world by keeping the social distance in view to stop the spread of COVID-19 disease. This conference aims is to present the current researches being carried out in the field of social science and education development around the globe.

Prospective authors from academia as well as industry are invited to submit their abstracts that illustrate original/unpublished works and industrial applications describing advances and significant innovations in the field. 


\section{International Advisory Committee}

- Prof. Dr. Flávio de São Pedro Filho, Coordinator of the GEITEC / UNIR / CNPq, Brazil; Federal University of Rondônia, Brazil

- Kofand Anwar, American Stratford University, Virginia

- Dr. Raghvendra Singh, Pranveer Singh Institute of Technology, India

- Dr. Mohammed Y. Suliman, Northern Technical University, Iraq

- José G. Vargas-Hernández, Núcleo Universitario Los Belenes CUCEA, Zapopan, Jalisco C.P. 45100; México

- Dr. Payal Chadha, University of Maryland University College Europe, Kuwait

- Dr. K. Srujan Raju, CMR Technical Campus (CMRG), CSI State Student Coordinator, Telangana State, India

- Prof. Dr. Eng. Ahmed Kadhim Hussein, College of Engineering, Department of Mechanical Engineering, Babylon University, Babylon City, HIILA , IRAQ

- Dr. M. Kannan, SCSVMV, Kanchipuram, India

- Mr. Sagar Jamle, Oriental University Indore, India

- Monica Aparecida da Rocha Silva, Universidade de São Paulo, Brazil

- Mohammed Y. Suliman, Northern Technical University, Iraq

- Mohd Muntjir, College of Computers and Information Technology, Taif University, Kingdom of Saudi Arabia 


\section{Message}

I am extremely pleased to share that International Research and Development Center for Publication (IRDCP) is organizing a two days International Conference on Engineering and Technology (E \& T- 2020) on Oct 26-27, 2020.

I am sure the state of art lectures from the invited experts and the research findings of researchers, academicians, utility engineers will enrich the knowledge of all the participants. It will provide an excellent opportunity for students to learn new ideas.

I offer my best wishes to the whole team of the organizing committee, the participants, and volunteers for the grand success of the conference.

Dr. Kiran

Convenor EARD-2020 


\section{Message}

I am happy to know that International Research and Development Center for Publication (IRDCP) is organizing a two days International Conference on Engineering and Technology (E \& T- 2020) on Oct 26-27, 2020. I am sure that, this conference would provide an ideal platform for the academicians, scholars and experts to present and exchange their research findings and Ideas.

I wish the conference a great success.

Dr. Praveen Kumar Jain 
Thinning and springback prediction of Mg alloy AZ31 in deep drawing process - Influence of BHF and friction conditions

Marina Maia Araripe, Francisco Elicivaldo Lima, Rômulo do Nascimento Rodrigues

Society 5.0 and Social Sciences

Sandro Serpa

\section{Social order and social networks}

Sandro Serpa

Optical gain analysis of type-II AlAsSb/InGaAs/GaAsSb nanoscale heterostructure under the effect of the external pressure

Jayprakash Vijay, Amit Rathi

The Use of Eye Gaze Gesture Interaction Artificial Intelligence Techniques for PIN Entry

Onyemauche Uchenna Chinyere, Osondu Blessing Ulumma, Etumnu Rosemary Chioma, Nwosu Quineth Ngozi

Student's Satisfaction Model in Open and Distance Learning Mode of

Education system: a structural equation modeling approach

Hitesh Choudhury, Dr. Tapashi Kashyap Das

Impact of pharmaceutical industry wastewater on photosynthetic pigments and proline content of Spirodela polyrhiza (L.) Schleid.

Khalida Parveen and Piyush Malaviya 


\section{Thermographic Image Classifier Using Transfer Learning}

Fausto Oliveira e Silva, Gustavo Maia de Almeida, Flávio Barcelos Braz da Silva 

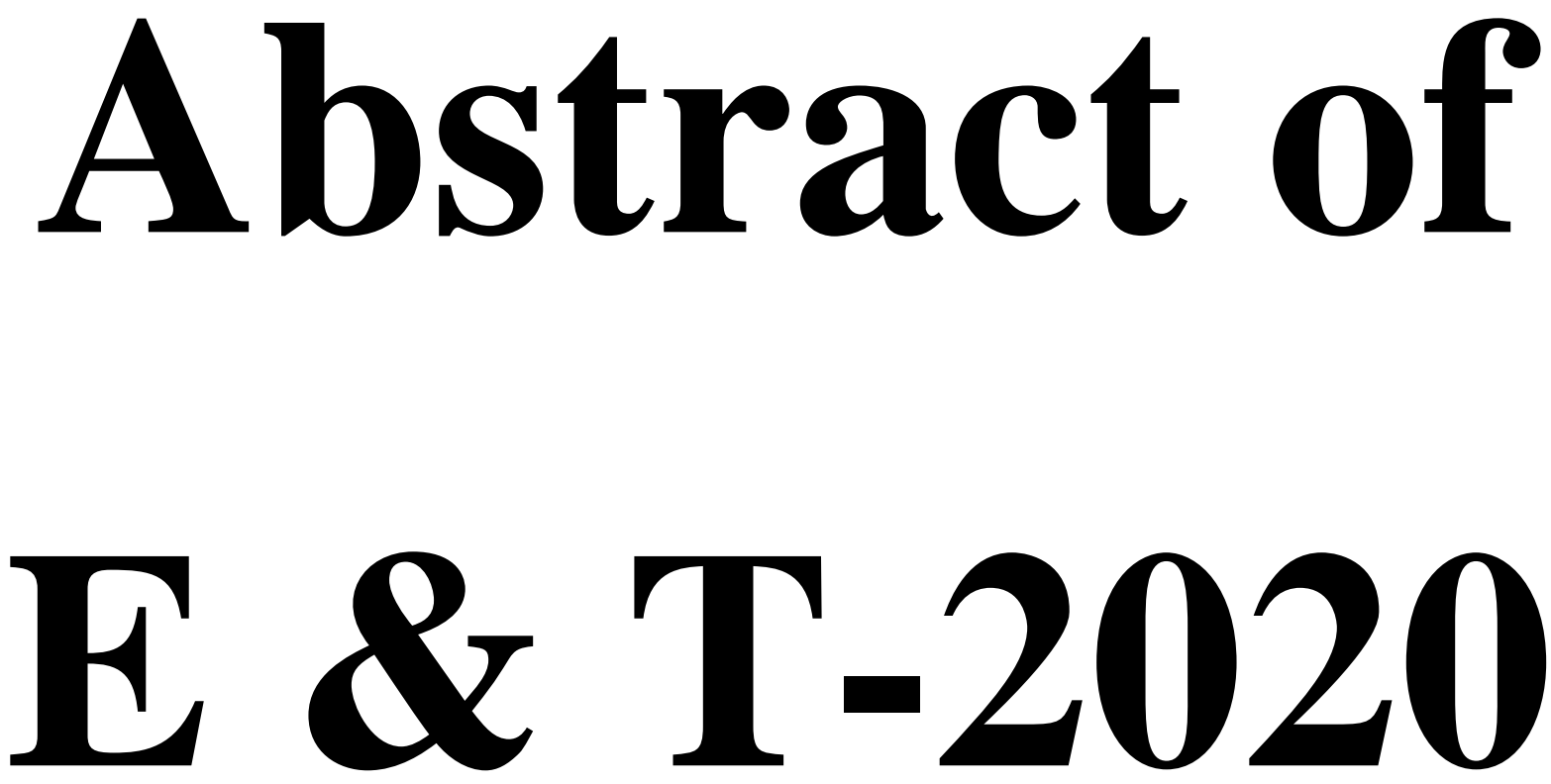


\title{
Thinning and springback prediction of Mg alloy AZ31 in deep drawing process - Influence of BHF and friction conditions
}

\author{
Marina Maia Araripe, Francisco Elicivaldo Lima, Rômulo do Nascimento \\ Rodrigues
}

Universidade Federal do Ceará, Fortaleza, Ceará, Brazil

\begin{abstract}
Magnesium is nowadays the lighter metal used in structural applications with expressive advantages over steel and aluminum. Due to its low density and high specific strength, magnesium alloys represent a promising alternative, especially for applications in automobile industry, being used in structural components in order to reduce weight and, consequently, improve fuel efficiency. In the recent decades, several researches have been performed in order to improve the use of $\mathrm{Mg}$ alloys in forming process since its formability is strongly affected by some conditions such as temperature. In this study, a Finite Element Analysis (FEA) is performed in order to simulate the sheet metal deep drawing process of the magnesium alloy AZ31. The main objective is to evaluate the effect of the blank holder force and friction conditions in the formability by predicting results of springback, thickness distribution and thinning of the sheet metal blank. In total, 54 simulations were performed.
\end{abstract}

Keywords - Blank holder force, Deep drawing, Finite elements, Friction, Lightweight alloy, Metal forming, Thickness distribution, Springback.

\section{References:}

[1] Sivanandini, M., Dhami, S. S., \& Pabla, B. S. (2012). Formability of magnesium alloys. Int. Journal of Modern Engineering Research, 2(4).

[2] Chang, Q. F., Li, D. Y., Peng, Y. H., \& Zeng, X. Q. (2007). Experimental and numerical study of warm deep drawing of AZ31 magnesium alloy sheet. International Journal of Machine Tools and Manufacture, 47(3-4), 436-443.

[3] Palaniswamy, H., Ngaile, G., \& Altan, T. (2004). Finite element simulation of magnesium alloy sheet forming at elevated temperatures. Journal of Materials Processing Technology, 146(1), 52-60. 
[4] Takuda, H., \& Hatta, N. (1998). Numerical analysis of formability of a commercially pure zirconium sheet in some sheet forming processes. Materials Science and Engineering: A, 242(1-2), 15-21.

[5] Mathaudhu, S., Luo, A., Neelameggham, N., Nyberg, E., \& Sillekens, W. (Eds.). (2016). Essential readings in magnesium technology. Springer.

[6] Cheng, Y. Q., Zhang, H., Chen, Z. H., \& Xian, K. F. (2008). Flow stress equation of AZ31 magnesium alloy sheet during warm tensile deformation. Journal of materials processing technology, 208(1-3), 29-34.

[7] Reddy, A. C. S., Rajesham, S., \& Reddy, P. R. (2015). Experimental and simulation study on the warm deep drawing of AZ31 alloy. Advances in Production Engineering \& Management, 10(3), 153.

[8] Lazarescu, L., Nicodim, I., \& Banabic, D. (2015). Evaluation of drawing force and thickness distribution in the deep-drawing process with variable blank-holding. In Key Engineering Materials (Vol. 639, pp. 33-40). Trans Tech Publications Ltd.

[9] Soualem, A. (2013). A Detailed Experimental Study of the Springback Anisotropy of Three Metals using the Stretching-Bending Process. International Journal of Mechanical and Mechatronics Engineering, 7(1), 144-147.

[10] Mang, T., \& Dresel, W. (Eds.). (2007). Lubricants and lubrication. John Wiley \& Sons. 


\title{
Society 5.0 and Social Sciences
}

Sandro Serpa

Faculty of Social and Human Sciences, Department of Sociology, University of the Azores; Interdisciplinary Centre of Social Sciences - CICS.UAc/CICS.NOVA.UAc; Interdisciplinary Centre for Childhood and Adolescence - NICA - UAc, the Azores, Portugal

\begin{abstract}
The digital society, in which the digital dimension permeates the interactions between individuals and the relationships between groups, is already among us, affecting even the processes of socialization and personal backup. One of its achievements could possibly and potentially be called Society 5.0. In understanding this Society 5.0 - a concept with a strong political component, the contribution of social sciences, by mobilizing an interdisciplinary perspective, is essential in fostering a critical literacy of this Society 5.0, which, like all processes, has potential advantages but also limitations in promoting sustainable social development.
\end{abstract}

Keywords - critical literacy, digital society, digitalization, social sciences, Society 5.0, sustainability digital innovations.

\section{References:}

[1] Ferreira, C. M., \& Serpa, S. (2018). Society 5.0 and social development: Contributions to a discussion. Management and Organizational Studies, 5(4), 26-31. https://doi.org/10.5430/mos.v5n4p26

[2] Ferreira, C. M., \& Serpa, S. (2019). Socialization: A key concept in Social Sciences. IJASOS- International E-Journal of Advances in Social Sciences, V(14), 599-605. https://doi.org/10.18769/ijasos.591428

[3] Santos, A. I., \& Serpa, S. (2020). Literacy: Promoting sustainability in a digital society. Journal of Education, Teaching and Social Studies, 2(1), 1-9. https://doi.org/10.22158/jetss.v2n1p1

[4] Serpa, S. (2019). Alienation on social media. Studies in Media and Communication, 7(1), 17-20. https://doi.org/10.11114/smc.v7i1.4286 
[5] Serpa, S., \& Ferreira, C. M. (2019a). Society 5.0 and sustainability digital innovations: Asocial process. Journal of Organizational Culture, Communications and Conflicts, 23(1), 1-14. Available at https://www.abacademies.org/articles/Society-5.0-and$\underline{\text { Sustainability-Digital-Innovations-A-Social-Process-1939-4691-23-1-129.pdf }}$

[6] Serpa, S., \& Ferreira, C. M. (2019b). Micro, meso and macro levels of social analysis. International Journal of Social Science Studies, 7(3), 120-124. https://doi.org/10.11114/ijsss.v7i3.4223

[7] Serpa, S., \& Ferreira, C. M. (2018). Goffman's backstage revisited: Conceptual relevance in contemporary social interactions. International Journal of Social Science Studies, 6(10), 74-80. https://doi:10.11114/ijsss.v6i10.3659

[8] Serpa, S., Ferreira, C. M., \&Santos, A. I. (2017). Fostering interdisciplinarity: Implications for social sciences.International Journal of Social Science Studies,5(12), 44-49. https://doi.org/10.11114/ijsss.v5i12.2775

[9] Serpa, S., Ferreira, C. M., Sá, M. J., \& Santos, A. I. (2020). Digital society and social dynamics. Birmingham,United Kingdom: Servicer for Science and Education. https://doi.org/10.14738/eb.17.2020

[10] Serpa, S., \& Santos, A. I. (2020). Critical literacy and literacies. Journal of Education, Teaching and Social Studies, 2(1), 18-23.https://doi.org/10.22158/jetss.v2n1p18 


\section{Social order and social networks}

Sandro Serpa

Faculty of Social and Human Sciences, Department of Sociology, University of the Azores; Interdisciplinary Centre of Social Sciences - CICS.UAc/CICS.NOVA.UAc; Interdisciplinary Centre for Childhood and Adolescence - NICA - UAc, the Azores, Portugal

Abstract - This presentation discusses the relationship between social order and social networks that are (re)created in the digital world. Elements such as alienation and fake news are emphasized, focusing the attention on the digital interaction of social (re)production.

Keywords - alienation, digital interaction, fake news, social isolation, social networks, social order.

\section{References:}

[1] Ferreira, C. M., \& Serpa, S. (2018). Society 5.0 and social development: Contributions to a discussion. Management and Organizational Studies, 5(4), 26-31. https://doi.org/10.5430/mos.v5n4p26

[2] Sá, M. J., Ferreira, C. M., \& Serpa, S. (2020). Science communication and online social networks: Challenges and opportunities. Knowledge Management: An International Journal, 19(2), 1-22. https://doi.org/10.18848/2327-7998/cgp/v19i02/1-22

[3] Santos, A. I., \& Serpa, S. (2017). The importance of promoting digital literacy in higher education. International Journal of Social Science Studies, 5(6), 90-93. https://doi.org/10.11114/ijsss.v5i6.2330

[4] Santos, A. I., \& Serpa, S. (2020). Literacy: Promoting sustainability in a digital society. Journal of Education, Teaching and Social Studies, 2(1), 1-9. https://doi.org/10.22158/jetss.v2n1p1

[5] Serpa, S. (2019). Alienation on social media. Studies in Media and Communication, 7(1), 17-20. https://doi.org/10.11114/smc.v7i1.4286 
[6] Serpa, S. (2020). 20 years in the academia: A selection of works. Hyderabad, Telangana, India: Avid Science. p. 104. eISBN: 978-93-88170-66-6. https://avidscience.com/book/20-years-in-the-academia-a-selection-of-works/

[7] Serpa, S., \& Ferreira, C. M. (2018). Sociological problem and social problem: Contributions to a discussion. Sociology and Anthropology, 6(11), 840844.https://doi.org/10.13189/sa.2018.061104

[8] Serpa, S., Ferreira, C. M., Sá, M. J., \& Santos, A. I. (2020). Digital society and social dynamics. Birmingham,United Kingdom: Servicer for Science and Education. https://doi.org/10.14738/eb.17.2020

[9] Serpa, S., Ferreira, C. M., \&Santos, A. (2020). Social representations of the Disadvantaged Childhood's Asylum of Horta in the press (Azores, Portugal): From the Constitutional Monarchy to the First Republic. Societies, 10(1), 4, 1-20. https://doi.org/10.3390/soc10010004

[10] Serpa, S., \& Santos, A. I. (2020). Critical literacy and literacies. Journal of Education, Teaching and Social Studies, 2(1), 18-23. https://doi.org/10.22158/jetss.v2n1p18 


\title{
Optical gain analysis of type-II AlAsSb/InGaAs/GaAsSb nanoscale heterostructure under the effect of the external pressure
}

\author{
Jayprakash Vijay ${ }^{1,2}$, Amit Rathi ${ }^{1}$ \\ ${ }^{1}$ Department of Electronics and Communication Engineering, Manipal University Jaipur \\ ${ }^{2}$ Department of Electronics and Communication Engineering, Swami Keshvanand Institute of \\ Technology, Management \& Gramothan, Jaipur \\ E-Mail: jpvijay121@gmail.com, amitrathi1978@gmail.com
}

\begin{abstract}
In this work, a novel design of AlAsSb/InGaAs/GaAsSb nanoscale heterostructure with two quantum well is proposed. The electronic and optical properties of the proposed structure are investigated theoretically with different material composition of the quantum well material layer and under the effect of external pressure. The simulation results indicate the designed quantum well structure is suitable for near-infrared applications such as optical fiber communication and spectroscopy in food production. The results also show that the emission wavelength and optical gain can be optimized under the effect of the external electric field. The optical gain in both TE and TM polarization mode are computed for the designed heterostructure. The entire structure has been modeled on the GaAs substrate at room temperature $300 \mathrm{~K}$.
\end{abstract}

Keywords - Quantum well, Polarization, Heterostructure.

\section{References:}

[1] Sang-Wan Ryu, P.D. Dapkus, "Optical characterization and determination of conduction band offset of type-II GaAsSb/InGaAs QW", Semiconductor science and technology, vol.-19, pp. 1369-1372, 2004.

[2] H. K. Nirmal, S.G.Anjum, Pyare Lal, Amit Rathi, S. Dalela, M. J. Siddiqui, P. A. Alvi, "Field effective band alignment and optical gain in type-1 $\mathrm{Al}_{0.45} \mathrm{Ga}{ }_{0.55} \mathrm{As} / \mathrm{GaAs}{ }_{0.84} \mathrm{P}_{0.16}$ nano-heterostructures", International Journal of light and electron optics: Optik vol.-127, pp.-7274-7282, 2016. 
[3] A.K.Singh, Md. Riyaj, S.G.Anjum, Nisha Yadav, Amit Rathi, M.J.Siddique, P.A. Alvi, "Anisotropy and optical gain improvement in type-II In0.3Ga0.7As/GaAs0.4Sb0.6 nano-scale heterostructure under external uniaxial strain", Superlattices and Microstructures 98(2016), 406-415.

[4] Md. Riyaj, A. K. Singh, Sandhya K., Amit Rathi, P. A. Alvi, “ Optical properties of Type-I GaAsPI AIGaAs nano-heterostructure under external uniaxial strain”, AlP Conference Proceedings, vol. 1832, no. I, 2017.

[5] E.V. Bogdanov, H. Kissel, K.1. Kolokolov, N. Ya Minina, "TM/TE polarization tuning and switching in tensile strained $\mathrm{pAIGaAs} / \mathrm{GaAsP} / \mathrm{n}-\mathrm{AIGaAs}$ heterostructures by uniaxial compression”, Semiconductor Science and Technology vol.-3 no.-31, 2016. 


\title{
The Use of Eye Gaze Gesture Interaction Artificial Intelligence Techniques for PIN Entry
}

Onyemauche Uchenna Chinyere ${ }^{1}$, Osondu Blessing Ulumma ${ }^{2}$, Etumnu Rosemary Chioma ${ }^{2}$, Nwosu Quineth Ngozi ${ }^{3}$

${ }^{1}$ Federal University of Technology Owerri, Imo State, Nigeria.
${ }^{2}$ Imo State College of Health Technology and Management Sciences, Amaigbo. Imo State Nigeria.

${ }^{2}$ Imo State College of Health Technology and Management Sciences, Amaigbo. Imo State Nigeria.

${ }^{3}$ University of Nigeria Nsukka, Enugu State, Nigeria.

\begin{abstract}
With an increasing number of computer devices around us, and the increasing time we spend for interacting with such devices, we are vehemently motivated in finding new interaction methods which ease the use of computers or increase interaction efficiency. Eye tracking seems to be a promising technology to achieve this goal. This paper researches interaction methods based on eye gaze tracking technology with emphasis in PIN entry. Personal identification numbers (PINs) are one of the most common ways of electronic authentication these days and they are used in a wide variety of applications. The PIN-entry user study used three different gaze-based techniques for PIN entry. The first and second method used gaze pointing to enter the PIN on a number pad displayed on the screen. The first method used a dwell time of 800 milliseconds and the second method used a button, which had to be pressed when looking at the correct number on the number pad display. The second method was introduced as hardware key or gaze key, but called look \& shoot method in the context of the user study as this name is self-explaining and got high acceptance by the participants. The third method used gaze gestures to enter the digits. The use of gaze gestures protects accidental input of wrong digits.
\end{abstract}

Keywords- Eye Tracker, Gaze Gesture, Human Computer Interaction, Personal Identification Number.

References: 
[1] De Luca M.A, Hansen, D. W., MacKay, D. J., Hansen, J. P., and Nielsen, L.M.(2007) Eye Tracking off the Shelf. In Proceedings of the 2004 Symposium on Eye Tracking Research \& Applications. ETRA '04. ACM Press (2007), 58 - 58.

[2] Fono, D., and Vertegaal, C. (2005). Touch-Typing With a Stylus. In Proceedings of the INTERACT '93 and CHI '93 Conference on Human Factors in Computing Systems CHI '93. ACM Press (2005), $80-87$.

[3] Foo T. K,(2013). Eye Gaze Based Reading Detection. In Conference on Convergent Technologies for Asia-Pacific Region, TENCON 2013. Volume 2, (2013) 825 - 828.

[4] Kumar, M., Paepcke, A., and Winograd, T. (2007). EyePoint: Practical Pointing and Selection Using Gaze and Keyboard. In Proceedings of the SIGCHI Conference on Human Factors in Computing Systems CHI '07. ACM Press (2007), 421 - 430.

[5] Land, M. F. (2006).Eye movements and the control of actions in everyday life. In Prog Retinal \& Eye Res (2006) 25: 296 - 324

[6] http://www.cis.rit.edu/pelz/scanpaths/papers/eye-movements-every-day-life-land2006.pdf)

[7] Schmidt, A.(2002) Ubiquitous Computing-Computing in Context, PhD Thesis. Lancaster University, 11/2002.

[8] http://www.comp.lancs.ac.uk/ albrecht/phd/Albrecht_Schmidt_PhDThesis_Ubiquitous-Computing_ebook1.pdf

[9] Vertegaal, R., Dickie, C., Sohn, C., and Flickner, M. (2015). Designing Attentive Cell Phone Using Wearable EyeContact Sensors. In CHI '15 Extended Abstracts on Human Factors in Computing Systems. CHI '15. ACM Press (2015), 646 - 647.

[10] Wobbrock, J. O., Rubinstein, J., Sawyer, M. W., Duchowski, A. T. (2007). Longitudinal Evaluation of Discrete Consecutive Gaze Gestures for Text Entry. In Proceedings of the 2007 Symposium on Eye Tracking Research \& Applications. ETRA '08. ACM Press (2007), 11 - 18. 


\title{
Student's Satisfaction Model in Open and Distance Learning Mode of Education system: a structural equation modeling approach
}

\author{
Hitesh Choudhury ${ }^{1}$, Dr. Tapashi Kashyap Das ${ }^{2}$ \\ ${ }^{1}$ Krishna Kanta Handiqui State Open University, Guwahati, Assam, India \\ ${ }^{2}$ Krishna Kanta Handiqui State Open University, Guwahati, Assam, India
}

\begin{abstract}
The main purpose of this study was to develop a student's satisfaction model in open and distance learning (ODL) mode of education system. There are different factors that can influence the student's satisfaction in ODL mode of education system, but in our study we have taken only three factors namely student's Technology Expertise, Flexibility of ODL mode of education system and Usefulness of ODL mode of education system. Here we proposed a model based on Technology Acceptance Model (TAM) with the above mentioned factors as a core constructs together with the construct satisfaction. The participants in this study were 196 learners who enrolled various graduate, postgraduate, diploma and certificate programmmes in different ODL institutions in North-East region. A self-designed questionnaire that comprises 19 items was administered as a tool for data collection. The collected data were coded and analyzed using SPSS AMOS v.23. Confirmatory Factor Analysis (CFA) and Structural Equation Modeling (SEM) were used to validate and explore the relationship among constructs of the model. The outcome of this study reveals that student's Technology Expertise, Flexibility and Usefulness significantly influenced the student's satisfaction in ODL mode of education system. Furthermore students Technology Expertise was found to be a significant predictor of Flexibility of ODL mode of education system.
\end{abstract}

Keywords - Open and Distance Learning, Technology Acceptance Model, Technology Expertise, Confirmatory Factor Analysis, Structural Equation Modeling. 


\section{References:}

[1] Dutta, A. Panigrahi, M. R. \& Ray, A. (2014), “Open and Distance Learning in India's North East: Status and Challenges”, COMOSA Journal of Open Schooling, 5(1), pp. 99114

[2] Nelasco, S., Arputharaj, A. \& Paul, G. (2007), "eLearning for Higher studies of India, Fourth International Conference on eLearning for Knowledge Society”, International Journal of the Computer, the Internet and Management, 15(3), pp. 162-167

[3] Choudhury, H. \& Khataniar, G. (2018), “Structural Equation Modeling for investigating the factors affecting the faculty members adoption and use of E-learning platform in academic purposes: An Empirical validation in higher educational context”, International Journal of Computer Science and technology, 7(2), pp. 21-29

[4] Fornell, C. \& Larcker, D. F. (1981), "Evaluating structural equation models with unobservable variables and measurement error", Journal of Marketing Research, Vol. 18, No. 1, pp. 39-50

[5] Hancock, G.R. \& Mueller, R.O. (2006), "Structural Equation Modeling: A second course. Charlotte, NC”, Information age publishing, Vol. 2, pp. 439-492

[6] Hu, L.T. \& Bentler, P.M. (1999), “Cutoff Criteria for fit indexes in covariance structure analysis: Conventional criteria versus new alternatives”, Structural Equation Modeling, Vol. 6, No. 1, pp. 1-55

[7] Pallant, J, (2013), SPSS survival manual. A step by step guide to data analysis using SPSS for windows 10, $4^{\text {th }}$ edition, Allen \& unwin 


\title{
Impact of pharmaceutical industry wastewater on photosynthetic pigments and proline content of Spirodela polyrhiza (L.) Schleid.
}

\author{
Khalida Parveen and Piyush Malaviya \\ Department of Environmental Sciences, University of Jammu, Jammu (J\&K), India
}

\begin{abstract}
The present study was conducted to assess the impact of pharmaceutical industry wastewater on photosynthetic pigments (chlorophyll a, chlorophyll b, total chlorophyll, carotenoid, anthocyanin) and proline content of Spirodela polyrhiza. The plants were exposed to $25,50,75$, and 100 percent effluent concentrations for seven days under laboratory conditions. The results of the study showed that chl a, chl b, total chlorophyll, anthocyanin and carotenoid content of Spirodela polyrhiza decreased significantly with increasing effluent concentration at all the exposure periods. On contrary, proline content of Spirodela was increased with both concentration and duration of exposure. The overall findings revealed that Spirodela polyrhiza positively respond to abiotic stress induced by pharmaceutical wastewater and can be used for the treatment of wastewater.
\end{abstract}

Keywords - Biochemical parameters, Pharmaceutical wastewater, Plant, Spirodela 


\title{
Thermographic Image Classifier Using Transfer Learning
}

\author{
Fausto Oliveira e Silva, Gustavo Maia de Almeida, Flávio Barcelos Braz da Silva
}

Federal Instituteof Espírito Santo,Serra,ES, Brazil

\begin{abstract}
The present work proposes to develop a tool to classify images generated from thermographic inspections. The proposal is to classify the situation of the equipment as normal and critical. For the development of this classifier, transfer learning techniques were used using already trained convolutional neural networks and recognition in the artificial intelligence environment.These networks have grown a lot in recent years and are being used in several applications that involve image classification. Finally, the work presents a comparison of a basic convolutional neural network and the VGG-16 and ResNet-50 networks that are already widespread in the midst of deep learning.
\end{abstract}

Keywords- Classifier, convolutional neural network, images, thermographic inspections, transfer learning.

\section{References:}

[1] BAGAVATHIAPPAN, S.; LAHIRI， B.B.; SARAVANAN， T.; PHILIP， J.; JAYAKUMAR, T. Infrared thermography for condition monitoring - A review. Infrared physics and technology, Set, 2013, Vol. 60, pp. 35-55.

[2] CHELlamuthU, S; SEKARAN, E. C. Fault detection in electrical equipment's images by using optimal features with deep lerning classifier. Multimedia Tools and Aplications. Out, 2019, Vol.78, pp. 27333-27350.

[3] GUO, T. et al. Simple convolution neural network on image classification. In: Big Data Analysis (ICBDA), 2017 IEEE 2nd International Conference on. IEEE, 2017, pp. 721724.

[4] HE, K.; ZHANG, X.; REN, S.; SUN, J. Deep residual learnin for image recognition. In: Proceedings of the IEEE conference on computer vision and pattern recognition. [S.I.: s.n], 2016. p. $770-778$ 
[5] HUDA, A. S. N.; TAIB, S. Suitable features selection for monitoring thermal condition of electrical equipment using infrared thermography. Infrared Physics And Technology, Nov 1, 2013, Vol.61, pp. 184-191.

[6] MLAKIC, D.; NIKOLOVSKI, S.; BAUS, Z. Detection of faults in electrical panels using deep learning method. International Conference on Smart Systems and Technologies (SST). Out, 2017, Osijek.

[7] WANDERLEY, M. D. S.; PRUDÊNCIO, R. B. C.; Transferring knowledge from texts to images by combining deep semantic feature descriptors. In: 2018 International Joint Conference on Neural Networks (IJCNN), on IEEE, 2018, pp. 1-7.

[8] YOSINSKI, J.; CLUNE, J.; BENGIO, Y.; LIPSON, H. How transferable are features in deep neural networks? In: Advances in neural information processing systems [S.I.: s.n.], 2014, pp. 3320-3328. 